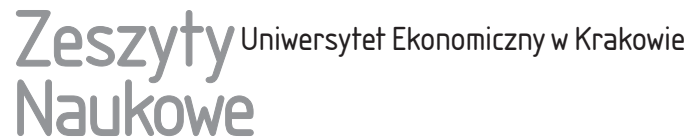

\section{Determinanty i skutki wahań koniunkturalnych na współczesnym rynku nieruchomości mieszkaniowych}

\section{Streszczenie}

Obserwacja funkcjonowania rynku nieruchomości mieszkaniowych wskazuje, że w jego rozwoju nie da się uniknąć cykliczności. Jest ona zaliczana do cech strukturalnych tego rynku. Na rynku nieruchomości mieszkaniowych występują ciągłe napięcia między sztywną w krótkim okresie podażą a zmiennym popytem. Pojawiające się stany nierównowagi mogą zanikać lub być przyczyną kryzysów. Z przeprowadzonych w artykule rozważań wynika, że obserwowane wahania koniunkturalne mogą być współcześnie dodatkowo wzmacniane przez system finansowy, zachowania spekulacyjne oraz interwencjonizm. Pojawia się wówczas niebezpieczeństwo kumulacji niekorzystnych zjawisk, a ich rezultatem jest z reguły powstawanie baniek cenowych, które mogą być przyczyną załamania rynku i kryzysu destabilizującego gospodarkę. Z analizy tych procesów wynika, że odpowiednia polityka oddziaływania na popyt mieszkaniowy może ograniczać ryzyko kryzysu. Stanowi to istotne wyzwanie dla instytucji publicznych. Jest to szczególnie ważne w sytuacji, gdy skutki ostatniego kryzysu nie zostały jeszcze do końca przezwyciężone, a na lokalnych rynkach nieruchomości mieszkaniowych obserwuje się w ostatnim okresie niepokojące zjawiska wzrostu cen sugerujące możliwość powstawania baniek cenowych.

Gabriel Główka, Szkoła Główna Handlowa w Warszawie, Kolegium Nauk o Przedsiębiorstwie, al. Niepodległości 162,02-554 Warszawa, e-mail: gabriel.glowka@sgh.waw.pl 
Słowa kluczowe: rynek nieruchomości mieszkaniowych, wahania koniunkturalne, bańka cenowa, stabilność systemowa.

Klasyfikacja JEL: E00, R00, R20.

\section{Wprowadzenie}

Rynek nieruchomości mieszkaniowych jest jednym z tych segmentów gospodarki, który oddziałuje stabilizująco na jej rozwój przez pozytywny wpływ na rozmiary zatrudnienia, poziom oszczędności i inwestycji oraz tempo wzrostu gospodarczego, ale może stać się również istotnym czynnikiem destabilizującym. Z obserwacji rynków mieszkaniowych wynika, że pojawiają się na nich cykliczne wahania poziomu cen oraz liczby budowanych mieszkań. Wahania te mogą być determinowane czynnikami fundamentalnymi, jak również mogą być rezultatem różnego rodzaju szoków zewnętrznych.

Celem artykułu jest identyfikacja, charakterystyka i ocena sposobu oddziaływania podstawowych czynników determinujących cykl koniunkturalny na współczesnym rynku nieruchomości mieszkaniowych. Jednym z istotnych warunków dających szansę na skuteczne prowadzenie polityki stabilizacji w celu łagodzenia negatywnych skutków wahań koniunkturalnych na rynku nieruchomości mieszkaniowych jest bowiem poznanie genezy i mechanizmu wywoływanych stanów nierównowagi na współczesnych rynkach mieszkaniowych. Dotyczy to w szczególności tych nierównowag, których rezultatem jest powstawanie baniek cenowych. Tego typu zjawiska są związane z ryzykiem naruszania stabilności systemowej kraju ze wszystkimi tego negatywnymi skutkami natury zarówno ekonomicznej, jak i społecznej.

Rozpoznanie tych zjawisk wydaje się szczególnie ważne w sytuacji, gdy skutki ostatniego kryzysu nie zostały jeszcze do końca przezwyciężone, a na lokalnych rynkach nieruchomości mieszkaniowych wystąpił w ostatnim okresie niepokojący wzrost cen sugerujący możliwość tworzenia się kolejnych baniek cenowych.

\section{Cykliczność jako strukturalna cecha rynku nieruchomości mieszkaniowych}

Zjawisko wahań poziomu aktywności gospodarczej znane jest od dawna, ale próbę jego zdefiniowania podjęto w połowie XIX w. Układ następujących po sobie wzrostowych i spadkowych zmian koniunkturalnych, które mają charakter cykliczny, tworzy cykl koniunkturalny (Barczyk i Lubiński 2009, s. 12). W. Szymański przedstawia w swej pracy ważniejsze teorie cyklu koniunkturalnego w gospodarce (2009, s. 137-138). Z kolei R. Barczyk dokonuje przeglądu 
współczesnych definicji i sposobów interpretacji cykli koniunkturalnych. Autor charakteryzuje również, opierając się na bogatym materiale empirycznym, morfologię współczesnych cykli koniunkturalnych, zarówno w krajach o rozwiniętej gospodarce rynkowej, jak i w krajach będących w okresie przebudowy systemu ekonomicznego. Omawia ich strukturę wewnętrzną ze szczególnym uwzględnieniem faz cyklu koniunkturalnego i występujących punktów zwrotnych (Barczyk 2006, s. 129-196).

Cyklom koniunkturalnym podlegają z różnym natężeniem wszystkie rodzaje rynków; jednym z nich jest rynek nieruchomości. A. Baum zauważa, że cykl koniunkturalny na rynku nieruchomości obrazuje wahania popytu, podaży, cen i stóp zwrotu z nieruchomości wokół ich długookresowych trendów bądź wartości przeciętnych (2001, s. 103-115). Cykl koniunkturalny na rynku nieruchomości opisywany jest również jako powracające, lecz nieregularne wahania poziomu globalnego dochodu z wszystkich rodzajów nieruchomości, widoczne również w zakresie innych wskaźników rynku nieruchomości, lecz z różnym wyprzedzeniem bądź opóźnieniem w stosunku do średniej z wszelkich rodzajów nieruchomości (Understanding... 1994, s. 9). Stanowi to ważne uzupełnienie definicji cyklu koniunkturalnego na rynku nieruchomości, gdyż określa charakter wahań cyklicznych. Wahania te mają charakter powtarzalny, ale nieregularny i w związku z tym dosyć trudno przewidywalny. Potwierdza to analiza tego rodzaju zmian na rynkach nieruchomości obserwowanych w przeszłości. Zmiany koniunkturalne nie przebiegają równolegle w czasie i podobnie na wszystkich rodzajach rynku nieruchomości. W literaturze podkreśla się odrębność i specyfikę poszczególnych rynków nieruchomości w tym zakresie (Su i Kelly 1995). Na pewno dość specyficzny pod tym względem będzie rynek nieruchomości mieszkaniowych, chociażby ze względu na istnienie jego różnych segmentów. W inny sposób zmiany będą przebiegały w głównym segmencie tego rynku służącym zaspokojeniu potrzeb mieszkaniowych, niż w drugim, równie ważnym segmencie inwestycyjnym.

Jedną z istotnych cech odrębności rynku nieruchomości mieszkaniowych w stosunku do innych rynków jest różny sposób jego zachowywania się w długim i krótkim okresie. W długim okresie zmiany na rynku nieruchomości mieszkaniowych determinowane są przez popyt, który określają czynniki fundamentalne, a dostosowania podaży następują przez budowę nowych mieszkań, jak również deprecjację istniejącego zasobu mieszkaniowego i mają charakter wieloletni. W długim okresie podaż uelastycznia się wraz z wydłużaniem się badanego okresu, jeśli tylko ceny pokrywają długookresowe koszty wytwarzania mieszkań. Ponadto na rynek nieruchomości mieszkaniowych może napływać nowy kapitał, który będzie powiększał możliwości zmian po stronie podaży. Można zatem stwierdzić, że w długim okresie rynek uruchamia mechanizmy wyrównujące 
dysproporcje między popytem a podażą. Dostosowania te jednak nie mogą z reguły zakończyć się osiągnięciem stanu równowagi rynkowej, gdyż zmiany popytowe są znacznie większe i następują w miarę często, poza tym obserwujemy w gospodarce zjawisko konkurowania rynków o inwestorów.

Rozpatrując natomiast funkcjonowanie rynku mieszkaniowego w krótkim okresie, można zaobserwować pojawiające się na nim zewnętrzne szoki popytowe, które uruchamiają mechanizmy krótkookresowych dostosowań. Krótkookresowe silne wzrosty popytu mieszkaniowego napotykają sztywną i mało elastyczną podaż mieszkań, zarówno w zakresie mieszkań zaoferowanych do sprzedaży w ramach istniejącego już zasobu, jak również nowego budownictwa. Ponieważ przyrost podaży jest przesunięty w czasie w stosunku do pojawiającego się impulsu wynikającego ze wzrostu popytu, powstają naturalne warunki do generowania cykli na rynkach mieszkaniowych, których efektem jest wzrost cen mieszkań i pojawianie się baniek spekulacyjnych. Z kolei efekty w postaci rosnącej liczby oddawanych do użytku nowych mieszkań, pojawiające się z opóźnieniem w stosunku do impulsu cenowego, często napotykają istotnie zmienioną sytuację na rynku. Przyrost podaży może okazać się nadmierny w stosunku do aktualnego poziomu popytu mieszkaniowego. Występuje wówczas zjawisko nadmiernej reakcji podaży na pojawiające się szoki popytowe na rynku nieruchomości mieszkaniowych. Istniejąca na rynku nierównowaga nie zanika zatem w wyniku działania klasycznego mechanizmu dochodzenia do równowagi. Skutkiem tego jest pogłębienie skali spadku cen mieszkań ze wszystkimi tego negatywnymi konsekwencjami. W sytuacji kumulacji wszystkich tych niekorzystnych czynników z reguły dochodzi do kryzysu na rynku nieruchomości, który może destabilizować system finansowy, a następnie gospodarkę kraju. Zależności pomiędzy stanem rynku nieruchomości mieszkaniowych a stabilnością makroekonomiczną potwierdzają wyniki badań (Andre i Girouard 2009).

Stopień zagrożenia kryzysem i prawdopodobieństwo wystąpienia w systemie ekonomicznym kryzysu wywołanego wysoką amplitudą wahań koniunkturalnych na rynku nieruchomości mieszkaniowych są trudne do oszacowania. Dzieje się tak pomimo stosowanych w praktyce wielu narzędzi i mierników służących badaniu i prognozowaniu koniunktury zarówno w całej gospodarce danego kraju, jak i w poszczególnych jej segmentach (Trojanek 2011; Klimkiewicz 2009, s. 167-176; Garczarczyk i Mocek 2009, s. 205-238). Wynika to głównie z tego, że powszechnie stosowane tradycyjne mierniki odzwierciedlają przede wszystkim fazę cyklu koniunkturalnego, a nie ryzyko wystąpienia takiego poziomu destabilizacji, której skutkiem będzie wywołanie głębokiego kryzysu. Rynek nieruchomości mieszkaniowych zachowuje się pod tym względem podobnie jak inne rodzaje rynków. Wydaje się, że w okresie ożywienia (pomyślnej koniunktury) ryzyko systemowe się obniża, a rośnie w fazie spadku (recesji). Tymczasem ryzyko 
rośnie w fazie ożywienia, co związane jest z narastaniem w okresie wzrostu koniunktury stanu nierównowagi rynkowej, która prowadzi do punktu zwrotnego w cyklu koniunkturalnym na rynku mieszkaniowym. Oznacza to zakończenie fazy wzrostu i rozpoczęcie fazy spadku. Opisane zjawisko określa się mianem luki percepcji ryzyka (risk perception gap) (Niedziółka 2009, s. 174).

\section{Diagnozowanie współczesnych wahań koniunkturalnych na rynku mieszkaniowym}

Podejmując próbę wskazania podstawowych uwarunkowań i czynników wywołujących cykl koniunkturalny na rynku nieruchomości mieszkaniowych, warto podkreślić, że bogata teoria dotycząca koniunktury gospodarczej jest, pomimo jej nieustannego rozwoju, zdaniem badaczy tych zjawisk ciągle zbiorem, „bardziej lub mniej udowodnionych prób wyjaśnienia mechanizmów gospodarczych, których efektem są określone zmiany aktywności gospodarczej” (Barczyk i Lubiński 2009, s. 33). R. Barczyk w pracy pt. Dylematy stabilizowania koniunktury przedstawił ewolucję poglądów w tym obszarze badań ekonomicznych (Barczyk i Lubiński 2009, s. 34-53).

Przyczyny występowania wahań koniunkturalnych na rynku nieruchomości mieszkaniowych mogą mieć charakter zarówno endogeniczny, jak i egzogeniczny. Za tradycyjne uwarunkowania wahań koniunkturalnych w przypadku tego rodzaju rynku uznaje się przyczyny o charakterze endogenicznym. Chodzi tutaj głównie o opóźnienia w dostosowywaniu się podaży do pojawiających się szybkich zmian w popycie. Wzrost popytu mieszkaniowego powodowany jest przede wszystkim przyrostem liczby gospodarstw domowych, migracjami ludności oraz wzrostem dochodów ludności. Pod wpływem oddziaływania tych czynników popyt mieszkaniowy może zmieniać się relatywnie szybko, natomiast odpowiedni przyrost podaży mieszkań wskutek ich wysokiej kapitałochłonności i długich cykli realizacji pojawia się bardzo często nawet po kilku latach. $Z$ reguły również przyrost liczby wybudowanych mieszkań jest ograniczony i niewystarczający. W następstwie tego rosną ceny mieszkań i sytuacja taka występuje do momentu pojawienia się bariery popytu. W okresie zbliżania się rynku do bariery popytu często poszukuje się oszczędności w zakresie kosztów budowy mieszkań oraz zwiększa się gęstość zabudowy. Wraz z pojawieniem się bariery popytu na mieszkania z reguły obserwowany jest na rynku spadek liczby transakcji, co prowadzi do spadku cen mieszkań i ograniczania liczby oddawanych do użytku mieszkań. Najczęściej zarówno spadek cen mieszkań, jak i ograniczenie liczby budowanych mieszkań nie mają wówczas charakteru gwałtownych zjawisk. Nie zawsze też negatywne skutki dekoniunktury na rynku mieszkaniowym są groźne dla całej gospodarki. 
Z obserwacji rynków nieruchomości mieszkaniowych wynika, że bańki cenowe o mniejszych rozmiarach, wywoływane czynnikami fundamentalnymi i będące skutkiem strukturalnych niedostosowań popytu i podaży na tym rynku, są $\mathrm{z}$ reguły stopniowo absorbowane przez realny spadek cen mieszkań w wyniku zarówno inflacji, jak również wzrostu dochodów i zdolności kredytowej gospodarstw domowych.

Z powyższych rozważań wynika, że rynek nieruchomości mieszkaniowych ma naturalne skłonności do generowania permanentnych stanów nierównowagi (Kucharska-Stasiak 2016). Stany nierównowagi wywoływane tradycyjnymi i fundamentalnymi czynnikami tkwiącymi w charakterze rynku mogą wygasać, ale mogą również być eksplozywne. Decydujący wpływ na to ma zachowanie się rynku nieruchomości mieszkaniowych determinowane zmianami zachodzącymi w jego otoczeniu, czyli czynnikami egzogenicznymi. Stan otoczenia rynku nieruchomości mieszkaniowych może powodować, że zmiany popytu i cen wynikające z czynników o charakterze fundamentalnym są tylko impulsem wywołującym powstanie bańki cenowej, której narastanie, wraz ze wszystkimi tego negatywnymi konsekwencjami, determinują czynniki zewnętrzne.

R.J. Shiller podzielił determinanty baniek cenowych na rynkach aktywów na czynniki powodujące ich narastanie (precipitating factors) oraz mechanizmy wzmacniające to zjawisko (amplifying mechanisms), potęgujące oddziaływanie tych poprzednich (Shiller 2005, s. 35-39). Czynników wzmacniających bańkę cenową na rynku nieruchomości mieszkaniowych jest wiele i wzajemnie się one przenikają. Do najważniejszych z nich można zaliczyć: funkcjonowanie systemu finansowego, zachowania uczestników rynku, interwencjonizm państwa oraz sposób regulacji rynku mieszkaniowego.

W dyskusjach naukowych dotyczących problemów koniunktury gospodarczej powszechnie wyrażane są poglądy, że sektor finansowy odgrywa istotną rolę w przebiegu cykli koniunkturalnych (Cantor i Wenninger 1993). Dotyczy to również praktyki funkcjonowania rynku nieruchomości mieszkaniowych. System finansowy jest obecnie bardzo mocno powiązany z rynkiem nieruchomości mieszkaniowych, co szczególnie mocno przejawia się w dwóch zasadniczych obszarach (Jajuga 2010). Pierwszy z nich dotyczy finansowania nieruchomości przede wszystkim za pomocą instrumentów finansowych zabezpieczonych hipotecznie na pierwotnym i wtórnym rynku mieszkaniowym. Drugi natomiast związany jest z szerokim zakresem inwestycji lokowanych na rynku nieruchomości. Dotyczy to zarówno możliwości inwestowania w nieruchomości w sposób bezpośredni, jak i w sposób pośredni, czyli inwestowania w różnego rodzaju instrumenty finansowe rynku nieruchomości, najczęściej zabezpieczone hipotecznie.

W rezultacie silnego powiązania rynku nieruchomości mieszkaniowych z sektorem finansowym występuje wyraźny związek między dynamiką cen 
mieszkań a dostępnością kredytu hipotecznego i skalą akcji kredytowej. W pełni uprawnione jest stwierdzenie, że czynnikiem wzmacniającym narastanie bańki cenowej na rynku mieszkaniowym i praźródłem kryzysu może stać się mechanizm nadmiernej ekspansji kredytowania hipotecznego. W sytuacji gdy wzrost cen nieruchomości mieszkaniowych wywołany naturalną cyklicznością rynku zostanie spotęgowany przez nadmierne kredytowanie hipoteczne, pojawia się bowiem z reguły bańka cenowa olbrzymich rozmiarów. Następnie dochodzi do jej gwałtownego pęknięcia, które skutkuje załamaniem rynku z wieloma tego bardzo negatywnymi konsekwencjami dla systemu bankowego i całej gospodarki. Doświadczenia ostatnich kilkudziesięciu lat wskazują na to, że nie jest możliwe zrozumienie współczesnych cykli koniunkturalnych na rynku nieruchomości mieszkaniowych bez uwzględnienia ich natury finansowej. Można nawet mówić o finansjalizacji cyklu koniunkturalnego na rynku nieruchomości mieszkaniowych. Pod pojęciem tym należy rozumieć radykalny wzrost roli i znaczenia czynników finansowych w przebiegu wahań koniunkturalnych na rynku mieszkaniowym. Jest to proces, który ma swe źródła w latach 70. ubiegłego wieku, ale dużego znaczenia nabrał w latach następnych w związku z szerokim zakresem deregulacji i liberalizacji rynków finansowych.

Rozważania na temat finansjalizacji gospodarki i jej konsekwencji podejmowane są w literaturze (Żyżyński 2006, Palley 2007, Barczyk, Lubiński i Małecki 2014). Do najistotniejszych konsekwencji tego zjawiska należy zaliczyć to, że współczesny system finansowy już nie tylko pośredniczy pomiędzy oszczędzającymi a inwestującymi i pełni funkcję służebną w gospodarce - doświadczenia pokazują, że może on funkcjonować samoistnie, w oderwaniu od sfery realnej gospodarki, i wywoływać różnego rodzaju szoki oraz generować cykle finansowe, które w zasadniczy sposób wpływają na cykle koniunkturalne w gospodarce, co określa się mianem ich finansjalizacji (Małecki 2016). Zjawiska te obserwujemy również na rynku nieruchomości mieszkaniowych. Badania pokazują, że to szoki finansowe stają się głównym źródłem wysokiej amplitudy wahań koniunkturalnych, a nie czynniki endogeniczne tkwiące w sferze realnej. Rynek nieruchomości mieszkaniowych staje się bowiem od pewnego czasu bardzo podatny na szoki finansowe, w tym przede wszystkim niebezpieczeństwo uruchomienia mechanizmu ekspansji kredytowania hipotecznego i wzrost znaczenia czynników spekulacyjnych w dynamice wzrostu cen mieszkań. Istnieje wówczas możliwość, jak to pokazują doświadczenia ostatniego kryzysu, uruchomienia samonapędzającego się mechanizmu wzrostu cen, oczekiwań cenowych i popytu. Popyt kreowany jest przez coraz mocniej konkurujące ze sobą banki, które ryzyko udzielanych kredytów oceniają przez pryzmat rosnących wartości ich hipotecznych zabezpieczeń (Siemińska 2009). Mamy wtedy najczęściej do czynienia z szybkim narastaniem bańki cenowej na rynku mieszkaniowym. 
Oznacza to, że system finansowania nieruchomości mieszkaniowych jest z jednej strony jednym z najistotniejszych czynników długofalowego rozwoju rynku mieszkaniowego, gdyż zwiększa dostępność mieszkań, z drugiej natomiast strony może stać się czynnikiem destabilizującym rynek mieszkaniowy przez kreowanie nadmiernego popytu w wyniku kierowania na ten rynek zbyt dużej ilości środków w postaci kredytów hipotecznych w fazie wzrostu koniunktury lub gwałtowne hamowanie popytu działaniami ograniczającymi kredytowanie rynku mieszkaniowego w okresie załamania się tendencji wzrostowych. W obu tych przypadkach może to oznaczać istotne zwiększanie amplitudy wahań na rynku mieszkaniowym, a negatywne tego skutki mogą oddziaływać destabilizująco w pierwszej kolejności na system bankowy. To z kolei z reguły prowadzi do zaburzeń w całej gospodarce. W pełni potwierdzają to doświadczenia płynące z kryzysów na rynkach nieruchomości. M. Iwanicz-Drozdowska stwierdza na podstawie przeprowadzonych badań, że: ,analiza współczesnych kryzysów bankowych wskazuje na to, że kredytowanie nieruchomości było często przyczyną pogarszania się kondycji banków (...). Jako przykłady mogą posłużyć USA, Japonia, Hiszpania i kraje skandynawskie. W każdym z tych krajów wystąpił kryzys bankowy o różnej sile i konsekwencjach, a jako jedną z ich przyczyn można podać załamanie się cen na rynku nieruchomości" (Iwanicz-Drozdowska 2007). Bardzo podobny charakter miał ostatni kryzys finansowy zapoczątkowany w 2007 r. Został on wywołany przez kryzys na amerykańskim rynku kredytów hipotecznych (Szymański 2009, s. 125 i nast.), ale zjawiska o podobnym charakterze pojawiły się również w Wielkiej Brytanii, Hiszpanii i wielu innych krajach.

$\mathrm{Z}$ przeglądu literatury przeprowadzonego na potrzeby niniejszego opracowania wynika jednak, że dla lepszego zrozumienia procesu narastania baniek cenowych na rynku nieruchomości mieszkaniowych, które mogą kreować ryzyko naruszania stabilności makroekonomicznej, niezbędne są pogłębione i kompleksowe badania otoczenia tego rynku. Przedmiotem zainteresowania powinny być nie tylko finansowe czynniki potęgujące narastanie baniek cenowych, ale również te o charakterze społecznym, kulturowym i instytucjonalnym.

Procykliczne oddziaływanie systemu finansowego może być wzmacniane przez zachowania konsumentów i inwestorów na rynku mieszkaniowym, ze szczególnym uwzględnieniem spekulacji i zachowań zbiorowych. Zjawiska te należy analizować, biorąc pod uwagę sposób postrzegania mieszkania jako dobra ekonomicznego. Mieszkanie może zaspokajać bezpośrednio potrzeby mieszkaniowe właściciela, ale także być przedmiotem działalności komercyjnej oraz spekulacji. W związku z tym popyt na mieszkania może być generowany przez osoby chcące zaspokoić swoje własne potrzeby mieszkaniowe, przez właścicieli - inwestorów, którzy zamierzają mieszkanie wynajmować, oraz przez spekulantów, którzy chcą mieszkanie tanio kupić i drogo sprzedać (Łaszek, Olszewski i Augustyniak 2017). 
W ujęciu historycznym mieszkanie jest przede wszystkim dobrem konsumpcyjnym służącym zaspokojeniu potrzeb mieszkaniowych właściciela, a także dodatkowo dość bezpieczną lokatą długoterminowych oszczędności. Wraz z rozwojem systemów finansowania nieruchomości i w rezultacie znacznie łatwiejszym dostępem do zewnętrznych środków finansowych wyraźnie zmienił się charakter mieszkania jako dobra ekonomicznego. W coraz większym stopniu jest ono traktowane jako dobro inwestycyjne, często będące przedmiotem zakupów spekulacyjnych.

Mieszkanie traktowane jako dobro inwestycyjne jest nabywane na rynku głównie z dwóch powodów. Po pierwsze, nabywcą może być inwestor kupujący mieszkanie w celu jego wynajmowania. Tego typu decyzje inwestycyjne mogą być wzmacniane, przy założeniu neutralnego nastawienia inwestora do ryzyka, przez utrzymywanie się stóp zwrotu z inwestycji w nieruchomości mieszkaniowe na wyższym poziomie niż nominalne stopy procentowe od kredytów i depozytów, a także niezbyt wysoki poziom instytucjonalnych ograniczeń możliwości upłynnienia mieszkań. Po drugie, motywem zakupu mieszkania mogą być cele spekulacyjne. Czynnikiem oddziałującym wówczas na zachowanie inwestora jest przekonanie o szybkim wzroście cen mieszkań. Na rynku mieszkaniowym można obserwować różne motywy spekulacji i zachowań zbiorowych (Augustyniak i in. 2012, s. 109). Wyróżnić można spekulację, która może mieć podłoże fundamentalne i być racjonalna, co oznacza, że kupujący mieszkanie może oczekiwać wzrostu jego ceny w przyszłości. Decyzje tego typu inwestorów o nabywaniu mieszkań (z uwagi na to, że będzie drożej) prowadzą do wzrostu ich cen. Spekulacja może również polegać na próbie uzyskania nadzwyczajnych zysków przez nabycie mieszkania i szybką jego sprzedaż po wzroście ceny. Mamy wówczas do czynienia z uwarunkowaniami dynamicznego wzrostu cen determinowanego czynnikami spekulacyjno-psychologicznymi.

Doświadczenia pokazują, że dla przebiegu cyklu koniunkturalnego na rynku mieszkaniowym zachowania spekulacyjne wynikające z przekonania uczestników rynku o dalszym nieuchronnym wzroście cen mieszkań mają istotne znaczenie. Deweloperzy, wspomagani przez pośredników kredytowych, prowadzą z reguły wówczas intensywne kampanie marketingowe, za pomocą których bardzo skutecznie potrafią przekonać potencjalnych nabywców mieszkań o dalszym wzroście cen i tym samym zachęcają do przyśpieszania decyzji o ich zakupie. W rezultacie tych działań pojawiająca się presja nadwyżkowego popytu umożliwiała deweloperom sprzedaż również nieistniejących mieszkań w liczbie i cenie znacznie wyższej, niż wynikałoby to z fundamentalnej równowagi rynkowej. Na rynku deweloperskim obserwujemy wtedy charakterystyczny dla boomu inwestycyjnego proces odkupywania terenów budowlanych przygotowanych do rozpoczęcia robót lub rozpoczętych już projektów mieszkaniowych. 
Powyższe uwarunkowania kreują dodatkowy, istotny impuls do wzrostu cen mieszkań. W rezultacie oczekiwania potencjalnych nabywców co do wzrostu cen mieszkań spełniają się, co tylko zwiększa oczekiwania dotyczące ich dalszego wzrostu w najbliższym czasie. Pojawia się wtedy z reguły przekonanie, że ceny mieszkań będą rosły zawsze. $Z$ reguły rośnie wówczas bańka cenowa olbrzymich rozmiarów, której pęknięcie grozi głębokim kryzysem na rynku nieruchomości, a następnie destabilizacją systemu bankowego, który najczęściej przez zbyt łatwy dostęp do pieniądza finansuje te nieracjonalne zakupy.

Kolejną grupą determinant tkwiących w otoczeniu rynku nieruchomości mieszkaniowych, które mogą potęgować narastanie bańki cenowej, są czynniki o charakterze społeczno-kulturowym. Na ich znaczenie zwrócili uwagę już kilkanaście lat temu R.J. Herring i S. Wachter (1999), którzy wyjaśniali występowanie cykli na rynku nieruchomości m.in. krótkowzrocznością inwestorów dotyczącą załamań rynku oraz ich nadmiernym optymizmem. Rola czynników tej natury w procesie kreowania baniek cenowych w tym segmencie gospodarki została potwierdzona w badaniach empirycznych przeprowadzonych przez A. Czerniaka (2014, s. 97-139). Z badań tych wynika, że istnieje kilka cech społeczno-kulturowych społeczeństw, które mogą powodować narastanie niebezpiecznych dla stabilności systemu ekonomicznego baniek cenowych na rynku mieszkaniowym. Należą do nich przede wszystkim: „uwarunkowany kulturowo optymizm, krótkookresowa orientacja w kulturze narodowej, niska skłonność do unikania niepewności oraz wysoki poziom zaufania w społeczeństwie" (Czerniak 2014, s. 140). Tego typu cechy otoczenia rynku mieszkaniowego mogą sprzyjać finansowaniu zakupu mieszkań z kredytów hipotecznych, podejmowaniu nadmiernego ryzyka kredytowego przez zarządzających bankami przy finansowaniu nieruchomości mieszkaniowych, formułowaniu przez uczestników rynku nadmiernie optymistycznych prognoz wzrostu cen mieszkań w krótkim okresie. W wyniku oddziaływania tych czynników możemy mieć do czynienia ze wzrostem podaży taniego pieniądza, co umożliwia irracjonalnie zachowującym się uczestnikom rynku zbyt łatwe zakupy mieszkań. Rosnący szybko wówczas popyt mieszkaniowy wpływa z reguły na nieracjonalne zachowania kolejnych inwestorów. Splot tych uwarunkowań może sprzyjać, w zależności od siły oddziaływania powyższych czynników w danym kraju, narastaniu bańki cenowej na rynku mieszkaniowym do rozmiarów zagrażających stabilności systemu ekonomicznego.

Miejsce potrzeb mieszkaniowych w hierarchii potrzeb człowieka, jak również rola rynku mieszkaniowego w gospodarce narodowej sprawiają, że jest to obszar objęty interwencją państwa, podejmowaną w ramach prowadzonej polityki mieszkaniowej (Lis 2012, s. 201-229). Władze publiczne podejmują rolę regulatora rynku nieruchomości mieszkaniowych, tworząc regulacje dotyczące przede wszystkim: planowania przestrzennego, prawa budowlanego, podatków oraz 
zasady wspierania możliwości zaspokajania potrzeb mieszkaniowych gospodarstw domowych przez użycie w tym celu środków publicznych. Polityka mieszkaniowa stanowi zatem istotny czynnik determinujący kształtowanie się popytu i podaży na rynku nieruchomości mieszkaniowych.

Wyniki badań wskazują, że interwencjonizm publiczny oraz jego zakres na rynku nieruchomości mieszkaniowych może być istotnym czynnikiem stabilizującym rynek, jak również stymulującym narastanie baniek cenowych (Interwencjonizm... 2013). W sytuacji kumulacji niekorzystnych czynników może to mieć dalekosiężne, negatywne skutki dla rynku mieszkaniowego i gospodarki kraju, ponieważ ze względu na dyskrecjonalny charakter interwencjonizmu publicznego niektóre z działań podejmowanych w jego ramach mogą mieć podobny efekt do zewnętrznych szoków rynkowych. $\mathrm{Z}$ obserwacji funkcjonowania rynków nieruchomości mieszkaniowych wynika, że największy wpływ na ich cykliczność mają przede wszystkim takie działania władz publicznych, jak:

- ekspansywna polityka banku centralnego, której efektem są niskie stopy procentowe oraz zasilanie banków komercyjnych ,tanim pieniądzem”, co sprzyja rozwojowi kredytowania hipotecznego i dynamice popytu mieszkaniowego;

- stosowanie różnego rodzaju dopłat do mieszkaniowych kredytów hipotecznych bądź oszczędności na cele mieszkaniowe. Wprowadzenie tego typu preferencji, korzystne ze względów społecznych, zwiększa dostępność kredytów na nabywanie mieszkań i tym samym presję na wzrost cen. Istnieje również niebezpieczeństwo, że część z tych kredytów po wygaśnięciu dopłat może okazać się kredytami zagrożonymi, gdyż osoby je zaciągające mogą nie zdawać sobie sprawy z przyszłych kosztów obsługi takiego zobowiązania (np. po wygaśnięciu dopłat do odsetek od kredytów w ramach polskiego programu rządowego „Rodzina na swoim");

- decyzje regulacyjne administracji publicznej w zakresie stosowania ulg podatkowych. Działania takie były podejmowane również w przypadku naszego kraju. System ulg i zwolnień w podatku dochodowym w ramach pomocy państwa w zaspokajaniu potrzeb mieszkaniowych stosowano w naszym kraju w znacznym zakresie. Warto przypomnieć chociażby o wprowadzeniu budowlanej ulgi odsetkowej, niższej stawki VAT w budownictwie mieszkaniowym, zwrocie części wydatków poniesionych na budowę własnego domu lub mieszkania. Z doświadczeń wynika, że bardzo niekorzystnie na kształtowanie się poziomu popytu i cen na rynku nieruchomości mieszkaniowych wpływają różnego rodzaju zapowiedzi władz publicznych o zamiarze dokonania zmian regulacyjnych, ze szczególnym uwzględnieniem zmian podatkowych. Mogą one wywoływać znaczny wzrost popytu i cen na rynku mieszkaniowym;

- działania na rzecz wspierania rozwoju rynku najmu mieszkań. Z badań wynika, że istotny wpływ na wahania cen na rynku nieruchomości mieszkanio- 
wych, a tym samym wahania makroekonomiczne ogółem, ma wielkość rynku najmu mieszkań w danym kraju (Czerniak i Rubaszek 2016, s. 24-35; Waszczuk 2017, s. 51-64). Odpowiednio ukształtowany rynek najmu może być alternatywą dla nabywania mieszkań na własność i spełniać istotną funkcję w równoważeniu rynku nieruchomości mieszkaniowych. Dzieje się tak ze względu na jego ważną rolę w ograniczaniu popytu i tym samym pozytywny wpływ na poziom cen mieszkań oraz możliwość pojawiania się baniek cenowych i prawdopodobieństwo kryzysu;

- nadzór finansowy, który w okresie narastania bańki cenowej na rynku mieszkaniowym często charakteryzuje się, jak to wynika z wcześniejszych doświadczeń, niewystarczającą aktywnością bądź spóźnioną reakcją na pojawiające się niekorzystne zjawiska. $Z$ kolei w czasie wybuchu kryzysu decyzje władz nadzorczych są często zbyt gwałtowne i polegają z reguły na nadmiernym podwyższaniu wymogów ostrożnościowych dotyczących kredytów hipotecznych, co powoduje duże ograniczenie dopływu środków kredytowych na rynek mieszkaniowy i pogłębienie kryzysu.

\section{Zakończenie}

Analiza mechanizmu funkcjonowania rynku nieruchomości mieszkaniowych wskazuje, że cykliczności w jego rozwoju nie da się uniknąć. Wahania koniunkturalne występujące na rynkach mieszkaniowych mają złożone uwarunkowania. Ich obserwacja pokazuje, że oprócz oddziaływania czynników fundamentalnych pojawiają się na poszczególnych rynkach szoki popytowe, które mogą zanikać lub wywoływać kryzysy. Zasadniczym problemem jest zatem to, czy możliwe jest skutecznie zapobieganie przekształcaniu się cykli koniunkturalnych na rynku mieszkaniowym w kryzysy destabilizujące gospodarkę. Wydaje się, że odpowiednie sterowanie przede wszystkim popytem mieszkaniowym może w sposób znaczący wpływać na zmniejszenie ryzyka powstawania baniek cenowych zagrażających stabilności systemowej.

Pojawia się zatem istotne wyzwanie dla instytucji publicznych dotyczące regulacji tego segmentu gospodarki, której celem byłoby prowadzenie działań ograniczających amplitudę wahań koniunkturalnych i tym samym ryzyko zaburzeń w funkcjonowaniu gospodarki. Konieczne będzie wykorzystanie do tego instrumentów polityki pieniężnej, jak również ostrożnościowych regulacji nadzorczych i odpowiedniej polityki mieszkaniowej. Kluczową kwestią jest zdolność do zastosowania takiego zakresu regulacji, który z jednej strony nie ograniczałby w sposób nieuzasadniony rozwoju rynku nieruchomości mieszkaniowych, a z drugiej umożliwiał skuteczne zabezpieczenie przed ryzykiem pojawiania się w jego rozwoju boomu cechującego się niestabilnością i kryzysów w systemie gospodarki. 


\section{Literatura}

Andre C., Girouard N. (2008), Housing Markets, Business Cyckles and Economic Policies (w:) Housing Market Challenges in Europe and the US. Any Solutions Available?, Austrian National Bank Workshop, Vienna.

Augustyniak H., Łaszek J., Olszewski K., Waszczuk J. (2012), Modelowanie cykli na rynku nieruchomości mieszkaniowych - uwzględnienie interakcji pomiędzy rynkiem pierwotnym oraz wtórnym i efekty mnożnikowe (w:) Raport o sytuacji na rynku nieruchomości mieszkaniowych i komercyjnych w Polsce w 2011 r., NBP, Warszawa.

Barczyk R. (2006), Morfologia cykli koniunkturalnych w gospodarkach rynkowych $i$ w systemach okresu transformacji (w:) R. Barczyk, L. Kąsek, M. Lubiński, K. Marczewski, Nowe oblicza cyklu koniunkturalnego, PWE, Warszawa.

Barczyk R., Lubiński M. (2009), Dylematy stabilizowania koniunktury, Wydawnictwo Uniwersytetu Ekonomicznego w Poznaniu, Poznań.

Barczyk R., Lubiński M., Małecki W. (2014), Banki a cykle koniunkturalne, Oficyna Wydawnicza SGH, Warszawa.

Baum A. (2001), Evidence of Cycles in European Commercial Real Estate Markets - and Some Hypotheses (w:) A Global Perspective on Real Estate Cycles, eds S. Brown, C. Liu, Springer, New York.

Cantor R., Wenninger J. (1993), Perspective on the Credit Slowdown, „FRBNY Quarterly Review", Spring.

Czerniak A. (2014), Wpływ cech społeczno-kulturowych społeczeństw na powstawanie baniek cenowych na rynku mieszkaniowym, SGH, Warszawa.

Czerniak A., Rubaszek M. (2016), Znaczenie prywatnego rynku najmu nieruchomości dla stabilności makroekonomicznej krajów strefy euro, Materiały i Studia, nr 325, NBP, Warszawa.

Garczarczyk J., Mocek M. (2009), Proste wskaźniki jakościowe koniunktury w prognozowaniu sytuacji na rynku usług finansowych (w:) Rynek usług finansowych a koniunktura gospodarcza, red. J. Garczarczyk, CeDeWu.pl, Warszawa.

Herring R.J., Wachter S. (1999), Real Estate Booms and Banking Busts: An International Perspective, The Wharton School - Financial Institutions Center Paper, nr 99-27.

Interwencjonizm a kryzysy na rynkach nieruchomości i kredytów hipotecznych (2013), red. L. Pawłowicz, B. Lepczyński, Instytut Badań nad Gospodarką Rynkową, Gdańsk.

Iwanicz-Drozdowska M. (2007), Znaczenie rynku nieruchomości dla bezpieczeństwa banków, „Finansowanie Nieruchomości”, nr 1.

Jajuga K. (2010), Instrumenty finansowe zabezpieczone hipotecznie (w:) Współczesna bankowość hipoteczna, red. A. Szelągowska, CeDeWu.pl, Warszawa.

Klimkiewicz J. (2009), Ocena koniunktury gospodarczej w Polsce na podstawie barometru i wybranych agregatów testu koniunktury IRG SGH (w:) Rynek usług finansowych a koniunktura gospodarcza, red. J. Garczarczyk, CeDeWu.pl, Warszawa.

Kucharska-Stasiak E. (2016), Rynek nieruchomości mieszkaniowych w procesie powstawania nierównowag makroekonomicznych, „Świat Nieruchomości”, $\mathrm{nr} 2$.

Lis P. (2012), Wahania cykliczne rynków mieszkaniowych. Aspekty teoretyczne i praktyczne, Wydawnictwo Adam Marszałek, Toruń.

Łaszek J., Olszewski K., Augustyniak H. (2017), Model popytu mieszkaniowego - analiza od strony właścicieli, właścicieli - inwestorów i inwestorów, „Kwartalnik Nauk o Przedsiębiorstwie", nr 2. 
Małecki W. (2016), Finansjalizacja cykli koniunkturalnych i jej konsekwencje dla polityki stabilizacyjnej, „Gospodarka Narodowa”, nr 4.

Niedziółka P. (2009), Kredytowe instrumenty pochodne a stabilność finansowa, Monografie i Opracowania, nr 563, SGH, Warszawa.

Palley T.I. (2007), Financialization: What It Is and Why It Matters, Political Economy Research Institute, Working Papers, nr 153, University of Massachusetts - Amherst.

Shiller R.J. (2005), Diverse Views on Asset Bubbles (w:) Asset Price Bubbles: The Implications for Monetary, Regulatory, and International Policies, red. W.C. Hunter, G.G. Kaufman, M. Pomerleano, MIT Press, Cambridge.

Siemińska E. (2009), Utrata wartości nieruchomości a problem adekwatności zabezpieczenia ekspozycji kredytowej, „Finansowanie Nieruchomości”, nr 1.

Su J., Kelly J. (1995), Property Cycles in European Office Markets, Jones Lang Wootton Research, London, June.

Szymański W. (2009), Kryzys globalny. Pierwsze przybliżenie, Difin, Warszawa.

Trojanek R. (2011), Wpływ wahań koniunkturalnych na lokalne rynki nieruchomości, „Studia i Materiały Towarzystwa Naukowego Nieruchomości”, vol. 19, nr 1.

Understanding the Property Cycle (1994), Report RICS.

Waszczuk J. (2017), Wpływ regulacji na kształtowanie sie relacji między rynkiem najmu a mieszkań własnościowych w wybranych krajach Unii Europejskiej (w:) Regulacje w optyce funkcjonowania przedsiębiorstw, red. T. Pakulska, SGH. Warszawa.

Żyżyński J. (2006), System finansowy a gospodarka realna: między służebnością a wyobcowaniem, „Ekonomista”, nr 4.

\section{Determinants and Effects of Economic Fluctuations on the Contemporary Residential Real Estate Market}

(Abstract)

The market mechanism on the residential real estate market shows that the cyclicality of its development will not be eliminated due to its structural features. The residential real estate market is characterized by continuous tensions between rigid short-term supply and variable demand. Emerging imbalances may just disappear but they also may lead to crises. The results of research presented in the paper show that market fluctuations observed on the residential property market can be strongly exacerbated by the financial system, speculation and interventionism. When that happens, the risk of accumulation of this unfavorable phenomenon arises. Price bubbles may form as a result, causing the market to collapse and crisis to destabilise the entire economy. However, the analysis of these threats shows that the appropriate policy on housing demand can reduce the risk of a crisis. This constitutes an important challenge for public institutions and is especially important since the effects of the most recent global crisis have not been completely resolved. Moreover, the residential housing markets have recently observed disturbing price rises, suggesting that price bubbles could occur in the near future.

Keywords: housing market, economic fluctuations, price bubble, systemic stability. 